\title{
Penerapan Metode User Centered Design Pada Rancang Bangun Sistem Penjualan Berbasis E-Commerce: Studi Kasus Toko Martijo 123
}

\author{
Armyta Megasari, Suhartini \& Muchlis \\ Sekolah Tinggi Manajemen Informatika dan Komputer Prabumulih \\ Email:Armytamegasari413@Gmail.Com
}

\begin{abstract}
The rapid growth of the E-Commerce market in Indonesia is indeed beyond doubt. With the number of internet users reaching 82 million or around $30 \%$ of the total population in Indonesia, the E-Commerce market is a gold mine which is very tempting for some people who can see the potential in the future. ECommerce is a form of changing patterns of interaction between sellers and buyers from direct physical contact and face-to-face to internet-based. With the stages of the User Centered Design method In this paper, the author uses the UML modeling language (Unifield Modeling Language) as a system design tool. From the system testing that has been done, the results displayed by the system when executed are in accordance with the design of the proposed system and interface system. with that stated the sales system has been successfully created in order to be able to help the Shop and Consumers to make the process of buying and selling online. The results of the study show that by identifying business needs, E-Commercebased sales systems can provide more interesting information features that can meet customer satisfaction. These features include search products, account information, shipping and payment confirmation. Another important factor is trust. In this process trust is the main capital. Because without the trust of both parties, the process of buying and selling E-Commerce can occur and be carried out.
\end{abstract}

Keywords: Shop, PHP, MySQL, UML, User Centered Design Method.

\section{Pendahuluan}

Dengan kemajuan teknologi yang sangat cepat khususnya di bidang komputer dan internet, hal tersebut sangat efektif untuk menciptakan sebuah karya. Komputer yang berperan sebagai media pengolahan data sangat penting dalam menyelesaikan pekerjaan. Selain itu komputer juga dapat digunakan untuk media komunikasi dengan menggunakan fasilitas internet, internet dapat memperluas wawasan ataupun menambah teman. Selain itu mereka juga dapat Persaingan dunia usaha, mendorong para pelaku bisnis dan badan usaha untuk dapat berubah dan mengikuti perubahan. Seperti halnya Proses penjualan online di Toko Martijo 123 saat ini hanya dilakukan melalui telepon dan media sosial seperti facebook, whatsapp, karena belum memiliki E-Commerce sehingga penjual masih kesulitan dalam pencetakan data transaksi dan laporan keuangan.

Dengan adanya penerapan sistem penjualan berbasis E-Commerce ini diharapkan dapat memudahkan penjualan dalam hal transaksi yang lebih efisien, pembuatan pengolahan data menjadi lebih cepat, membantu penjualan barang menjadi lebih akurat dan dapat mempermudah konsumen dalam melakukan pemesanan produk. Oleh karena itu, penulis tertarik untuk membangun sebuah sistem yang berjudul "Penerapan Metode User Centered Design Pada Rancang Bangun Sistem Penjualan Berbasis E-Commerce (Studi Kasus Toko Martijo 123)". 


\section{Tinjauan Literatur}

\subsection{UCD (Metode User Centered Design)}

Menurut ISO 13407 yang dikutip oleh Jelita dalam jurnal Komputa. ISSN:2089-9033 menjelaskan bahwa User Centered Design (UCD) adalah sebuah filosofi perancangan yang menempatkan pengguna sebagai pusat dari sebuah proses pengembangan sistem. Metode ini didasarkan oleh kebutuhan dan kondisi dari para konsumen Toko Martijo 123 sebagai pengguna dan dikaitkan dengan konsep dari UCD yang menempatkan pengguna sebagai pusat dari proses pengembangan sistem.

\subsection{Rancang Bangun}

Menurut Bambang (2013:27) yang dikutip oleh Yuntari dalam jurnal Jsk. ISSN:25794477 Vol.1 No.1 juni (2017), Menjelaskan bahwa rancang bangun adalah proses pembangunan sistem untuk menciptakan sistem baru maupun mengganti atau memperbaiki sistem yang telah ada baik secara keseluruhan maupun hanya sebagian.

Menurut Imam D (2016), yang dikutip oleh Fajryah dan Ahmad Josi dalam jurnal Sisfokom (2017), menjelaskan bahwa rancang bangun adalah suatu istilah umum untuk membuat atau mendesain suatu objek dari awal pembuatan sampai akhir pembuatan.

\subsection{Sistem Penjualan}

Menurut Mulyadi (2008:202), yang dikutip oleh Mikhael Ferdika dalam jurnal Information System for Educators And Professionals. ISSN:2548-3587. Vol. 1 No. 2 (2017), menjelaskan bahwa Penjualan merupakan kegiatan yang dilakukan oleh penjual dalam menjual barang atau jasa dengan harapan akan memperoleh laba dari adanya transaksi-transaksi tersebut dan penjualan dapat diartikan sebagai pengalihan atau pemindahan hak kepemilikan atas barang atau jasa dari pihak penjual ke pembeli.

\subsection{E-Commerce}

Menurut I Putu Agus (2015:1), E-Commerce merupakan bentuk perubahan pola interaksi antara penjual dan pembeli dari kontak fisik dan tatap muka langsung menjadi berbasiskan internet dan pemasaran global yang lebih meluas. E-Commerce memberikan banyak manfaat bagi para pelaku ekonomi, baik penjual maupun pembeli. Dapat diketahui manfaat E-Commerce di dalam membantu pengguna komputer, baik pelaku bisnis (pedagang, distributor, produsen) maupun konsumen akhir.

\subsection{Pengertian Website}

Menurut Rahman Su (2017:1), “website adalah media yang akan meng antarkan usaha Anda merabah dan menjelajah di dunia maya, sehingga banyak orang dari belahan dunia mana pun bisa mengetahui keberadaan usaha Anda melalui website Anda tersebut".

\subsection{PHP}

Menurt Jubilee Enterprise (2017:1). PHP merupakan bahasa pemograman yang dilakukan untuk membuat aplikasi berbasis website. Berikut ini beberapa tipe (jenis) data yang ada didalam lingkungan $P H P$ yang sering ni adalah jenis data interger, float, string, array, objek dan Boolean.

\subsection{Bootstrap}

Menurut Eko Priyo Utomo (2016:11), "bootstrap" merupakan salah satu framework $H T M L, C S S$, dan JS yang cukup populer, serta banyak digunakan untuk membuat website 
yang bersifat responsif. Artinya bisa menyesuaikan tampilan layout-nya berdasarkan ukuran viewport dari devies pengaksesnya, mulai dari smartphone, tablet atau layar PC.

\subsection{MySQL}

MySQL merupakan database yang pertama kali didukung oleh bahasa pe-mograman script untuk internet (PHP dan Perl). MySQL dan PHP dianggap sebagai pasangan software pembangun aplikasi web yang ideal. $M y S Q L$ lebih sering digunakan untuk membangun aplikasi berbasis web.

\subsection{Xатpp}

Pada umumnya Xampp merupakan perangkat lunak bebas dan mendukung berbagai macam sistem operasi. Fungsi dari Xampp digunakan untuk server localhost atau server yang berdiri sendiri dan terdiri dari beberapa program seperti perl, apache htppserver, penterjemah bahasa yang sudah ditulis sesuai dengan bahasa pemrograman pop, dan MySQL databse.

\subsection{Database}

Menurut Rohi Abdullaoh (2018:103). "Database atau basis data adalah kumpulan dari informai yang disimpan dalam komputer yang disimpan secara sistematik sehingga dapat diperiksa menggunakan suatu program komputer untuk memperoleh informasi". Dapat disimpulkan bahwa basis data merupakan kumpulan relasi-relasi dari data yang dapat digunakan untuk mmperoleh informasi yang dibutuhkan oleh perusahaan.

\subsection{UML (Unified Modeling Language)}

Menurut Rosa A.S dan M. Shalaludin (2015:137), UML(Unified Modeling Language) adalah bahasa visual untuk pemodelan dan komunikasi sebuah sistem dengan menggunakan diagram dan teks-teks pendukung. Pemodelan sesungguhnya digunakan untuk menyederhanakan permasalahan-permasalahan.

\section{a. Use Case Diagram}

Use case diagram mendeskripsikan sebuah interaksi antara satu atau lebih actor dengan sistem informasi yang akan dibuat, dan untuk mengetahui fungsi apa saja yang ada di dalam sebuah sistem informasi dan siapa saja yang berhak menggunakan fungsi-fungsi itu.

Berikut ini adalah simbol-simbol yang ada pada diagram use case:

Tabel 2.1 Diagram Use Case Proses

\begin{tabular}{|c|c|}
\hline Gambar & Keterangan \\
\hline
\end{tabular}




\begin{tabular}{|c|l|}
\hline Aktor / Actor & $\begin{array}{l}\text { Orang, proses, atau sistem lain yang berinteraksi } \\
\text { dengan sistem informasi yang akan dibuat diluar } \\
\text { sistem informasi yang akan dibuat itu sendiri, jadi } \\
\text { walaupun simbol dari aktor adalah gambar orang, } \\
\text { biasanya dinyatakan dalam menggunakan kata } \\
\text { benda diawal frase nama aktor. }\end{array}$ \\
\hline Asosiasi / Association & $\begin{array}{l}\text { Fungsionalitas yang disediakan sistem sebagai } \\
\text { unit-unit yang saling bertukar pesan antar aktor }\end{array}$ \\
\hline Ekstensi / extend & $\begin{array}{l}\text { Remunikasi antara aktor dan use case yang } \\
\text { dimana } \text { use case yang ditambahkan dapat berdiri } \\
\text { sendiri walau tanpa use case tambahan. }\end{array}$ \\
\hline$-9-j$ & $\begin{array}{l}\text { Hubungan generalisasi dan spesoalisasi antara } \\
\text { dua buah use case dimana fungsi yang satu adalah } \\
\text { fungsi yang umum dari yang lain }\end{array}$ \\
\hline Generalisasi &
\end{tabular}

\section{b. Activity Diagram}

Activity Diagram menggambarkan Workflow (Aliran kerja) atau aktivitas dari sebuah sistem atau proses bisnis atau menu yang ada pada perangkat lunak. Yang perlu diperhatikan disini adalah bahwa diagram aktivitas menggambarkan aktivitas sistem bukan apa yang dilakukan aktor, jadi aktivitas yang dapat dilakukan oleh sistem.

Tabel 2.2 Simbol-Simbol Activity Diagram

\begin{tabular}{|c|l|l|}
\hline \multicolumn{1}{|c|}{ Simbol } & \multicolumn{1}{|c|}{ Nama } & \multicolumn{1}{c|}{ Keterangan } \\
\hline Start & Kondisi Awal & $\begin{array}{l}\text { Menunjukan awal dari suatu diagram } \\
\text { Aktivitas }\end{array}$ \\
\hline End & Kondisi Akhir & $\begin{array}{l}\text { Menunjukan akhir dari suatu diagram } \\
\text { Aktivitas }\end{array}$ \\
\hline
\end{tabular}




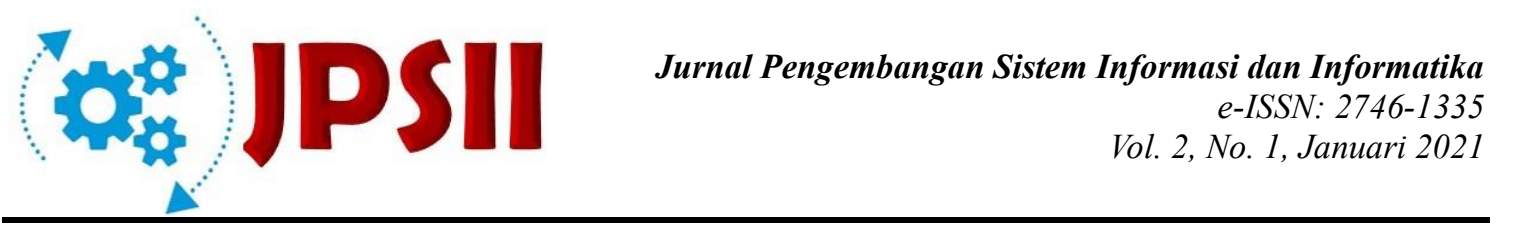

\begin{tabular}{|l|l|l|}
\hline & Kondisi transisi & $\begin{array}{l}\text { Menunjukan kondisi transisi antar } \\
\text { Aktivitas }\end{array}$ \\
\hline \begin{tabular}{c}
\hline Swimane \\
\hline
\end{tabular} & Swimlane & $\begin{array}{l}\text { Menunjukan aktor dari diagram aktivitas } \\
\text { yang dibuat }\end{array}$ \\
\hline$>$ & Aktivitas & $\begin{array}{l}\text { Menunjukan aktivitas-aktivitas yang } \\
\text { terdapat pada diagram aktivitas }\end{array}$ \\
\hline & $\begin{array}{l}\text { Pengecekan } \\
\text { kondisi }\end{array}$ & $\begin{array}{l}\text { Menunjukan pengecekan terhadap suatu } \\
\text { kondisi }\end{array}$ \\
\hline
\end{tabular}

c. Class Diagram

Class Diagram menggambarkan struktur sistem dari segi pendefinisian kelas-kelas yang akan dibuat untuk membangun sistem. Kelas ada yang disebut atribut dan metode atau operasi. Atribut merupakan variabel-variabel yang dimiliki oleh suatu kelas. Operasi atau metode adalah fungsi-fungsi yang dimiliki oleh suatu kelas.

Tabel 2.3 Simbol - Simbol Class Diagram

\begin{tabular}{|c|c|}
\hline Simbol & Keterangan \\
\hline Kelas & Kelas pada struktur system \\
\hline nama_kelas & \\
\hline +atribut & \\
\hline +operasi() & \\
\hline$\bigcirc^{\text {Antarmuka }}$ & $\begin{array}{l}\text { Sama dengan konsep interface dalam pemograman } \\
\text { berorientasi objek }\end{array}$ \\
\hline$\stackrel{\text { Asosiasi berarah }}{\longrightarrow}$ & $\begin{array}{l}\text { Relasi antarkelas dengan makna kelas yang satu } \\
\text { digunakan oleh kelas yang lain }\end{array}$ \\
\hline
\end{tabular}




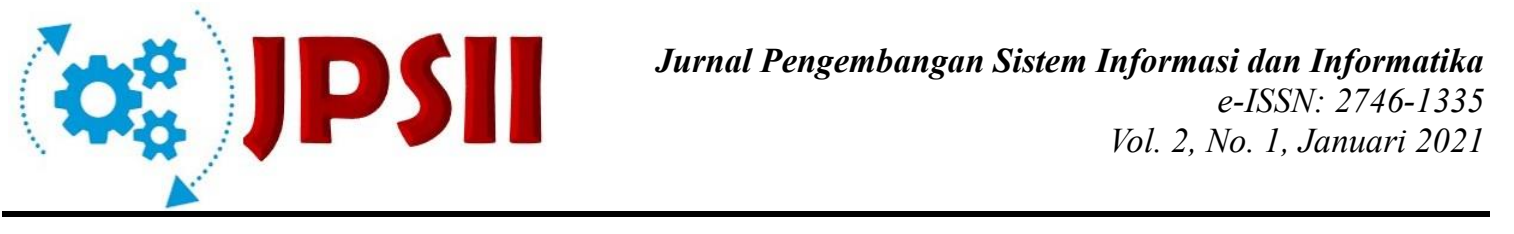

\begin{tabular}{|c|l|}
\hline Asosiasi & $\begin{array}{l}\text { Relasi antarkelas dengan makna umum, asosiasi } \\
\text { biasanya juga disertai multiplicity }\end{array}$ \\
\hline Generalisasi & Relasi antarkelas antara generalisasi dan spesialisasi \\
\hline Agregasi & Relasi antar kelas dengan makna semua bagian \\
\hline &
\end{tabular}

\section{Metode Penelitian}

\subsection{Objek Penelitian}

Pada penyusunan penelitian ini penulis mengambil objek penelitian pada Toko Martijo yang terletak di Jalan Sumatra Gunung Ibul No.1 RT.03 RW.05 Kecamatan Prabumulih Timur.

\subsubsection{Struktur Organisasi}

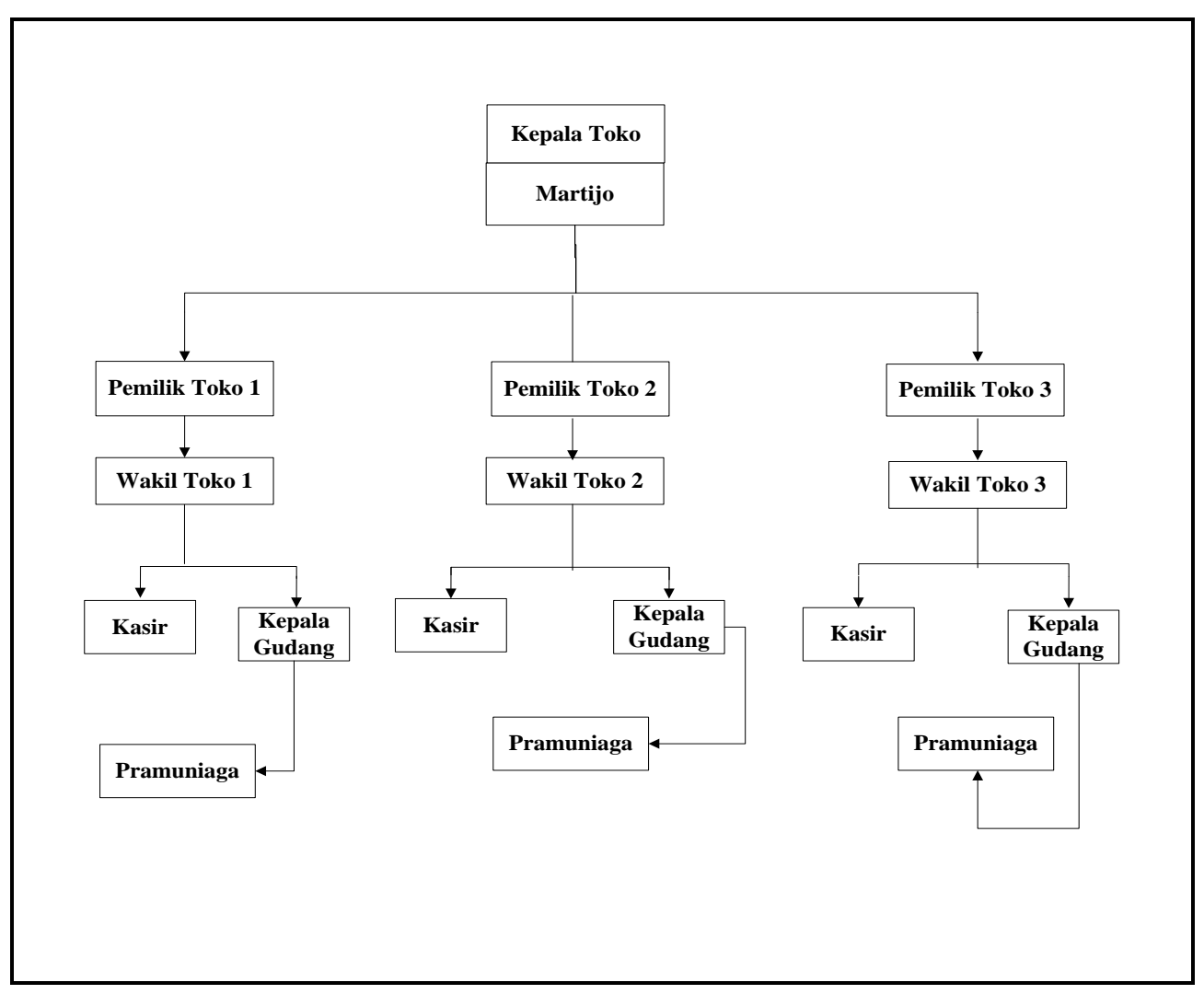

Gambar 3.1 Struktur Organisasi

Sumber data : Toko Martijo (2018) 


\subsection{Metode Penelitian}

Menurut Sugiyono (2015:2). Metode penelitian dapat diartikan sebagai cara ilmiah untuk mendapatkan data yang valid dengan tujuan dapat ditemukan, dikembangkan, dan dibuktikan, suatu pengetahuan tertentu sehingga dapat digunakan untuk memahami, memecahkan, dan mengatisipasi masalah. Metode yang digunakan penulis adalah metode penelitian deskriptif.

\subsection{Desain Penelitian}

Menurut Nazir Moh. (2011:84) desain dari penelitian adalah semua proses yang dilakukan dalam perencanaan dan pelaksanaan penelitian. Dalam pengertian yang lebih sempit, desain penelitian hanya mengenai pengumpulan dan analisis data saja. Proses perencanaan penelitian dimulai dari identifikasi, pemilihan serta rumusan masalah, sampai dengan perumusan hipotesis serta kaitannya dengan teori dan kepustakaan yang ada.

\subsection{Metode Pengembangan Sistem}

\subsubsection{Metode UCD (User Centered Design)}

Dikutip oleh Riko Mangasi Simatupang (2014), dalam jurnal Inti. ISSN : 2339-210X. Menjelaskan bahwa Metode User Centered Design (UCD) muncul dengan membawa konsep pengembangan suatu produk baik itu perangkat lunak (website) maupun perangkat keras berorientasi pada pengguna dapat menjadi solusi untuk mengetahui apa yang menjadi keinginan pengguna. User merupakan objek yang penting di dalam pengembangan sistem. User disini adalah pribadi, organisasi, dan masyarakat.

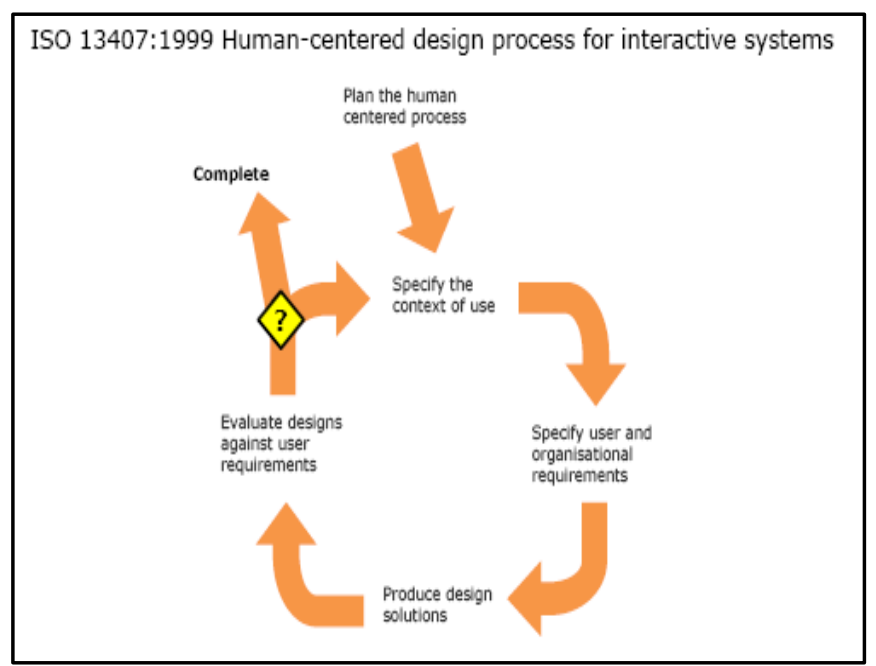

Gambar 3.2 Proses UCD Berdasarkan ISO 13407:1999

\subsubsection{Pembahasan Proses $U C D$}

Untuk merancang sistem penjualan Toko Martijo 123, penulis menterjemahkan langkah demi langkah yang ada dalam proses $U C D$ implementasi tindakan sebagai berikut:

1. Memahami dan Menentukan Konteks Pengguna

Tahap ini peneliti mengindentifikasi orang yang akan menggunakan sistem dan menjelaskan untuk apa dan dalam kondisi apa mereka akan menggunakan produk ini 
melalui teknik identify stageholder. Sistem ini dirancang untuk menyediakan informasi berupa web tentang produk yang ditawarkan oleh Toko Martijo 123. Sasaran pengguna dari sistem ini terdiri dari 2 pengguna:

a. Konsumen dapat mengakses informasi tentang produk apa saja yang di jual oleh pihak Toko.

b. Admin yang berperan dalam mengelola dan memelihara data pada sistem.

2. Mementukan Kebutuhan Pengguna dan Organisasi

Tahap ini peneliti akan mengidentifikasi tahap daftar rincian dari kebutuhan pengguna melalui teknik wawancara.

a. Kebutuhan Informasi

Data kewilayahan Kota Prabumulih, data lokasi Toko Martijo 123, data laporan penjualan online Toko Martijo.

b. Kebutuhan Fungsional

Memiliki fasilitas administrator untuk mengelolah data, mampu menampilkan informasi tentang produk yang di tawarkan Toko Martijo 123, mampu melakukan transaksi secara online.

c. Kebutuhan Non Fungsional

Sistem memiliki fasilitas otentifikasi untuk login ke halaman administrator, mampu menampilkan informasi tentang detail produk, sistem dapat diakses dimana saja selama terkoneksi dengan internet.

3. Solusi Perancangan yang Dihasilkan

Tahapan ini merupakan tahap perancangan solusi. Dimana peneliti akan membangun design sebagai solusi dari sistem yang sedang di analisis.

a. Tampilan Halaman Utama

Tampilan halaman menu utama ini berisikan halaman awal dari website Toko Martijo yang berisikan katalog penjualan.

b. Tampilan Halaman Admin

Admin melakukan login untuk dapat masuk ke halaman bagian administrasi dan memiliki hak akses sistem penjualan yaitu dan dapat melakukan pengolahan data barang, halaman kategori, halaman pemesanan, halaman pembayaran dan halaman laporan pemesanan.

4. Evaluasi Perancangan Terhadap Kebutuhan Pengguna

Tahap ini merupakan tahap evaluasi terhadap perancangan yang telah disesuaikan dengan kebutuhan pengguna. Evaluasi ini dilakukan untuk mengetahui sejauh mana perancangan yang akan dihasilkan sesuai dengan kebutuhan pengguna.

\subsubsection{Pengujian Software}

Pada penelitian ini metode yang akan digunakan dalam pengujian perangkat lunak yang dihasilkan adalah dengan menggunakan black box testing Menurut A.S Rosa dan Shalahuddin (2014:275) black box testing (pengujian kotak hitam) yaitu menguji 
perangkat lunak dari segi spesifiksi fungsional tanpa menguji desain dan kode program. Pengujian dimaksudkan untuk mengetahui apakah fungsi-fungsi masukan, dan keluaran dari perangkat lunak sesuai dengan spesifikasi yang dibutuhkan. Pengujian kotak hitam ini dilakukan dengan membuat kasus uji yang bersifat mencoba semua fungsi dengan memenuhi.

\section{Hasil dan Pembahasan}

\subsection{Implementasi}

Tahap implementasi merupakan suatu proses untuk mendapatkan dan menerapkan informasi dalam operasi supaya dapat dioperasikan. Pada tahapan ini dijelaskan mengenai, Implementasi Perangkat Lunak, Implementasi Perangkat Keras, Implementasi Antar Muka.

\subsubsection{Implementasi Perangkat Lunak}

Pada bagian ini akan dijelaskan tentang perangkat lunak yang digunakan sebagai media implementasi sistem penjualan yang dihasilkan dari penelitian. Perangkat lunak yang dibutuhkan untuk implementasi sistem penjualan pada Toko Martijo 123 adalah sebagai berikut:
1. Sistem Operasi
: Windows 10
2. Pembuatan Basis Data : Xampp Control Panel
3. Browser
: Mozilla Firefox
4. Bahasa Pemograman :Bootstrap dan PHP

\subsubsection{Implementasi Perangkat Keras}

Perangkat keras (hardware) yaitu komponen fisik bersifat dapat dilihat, disentuh, dan berbentuk nyata yang membentuk satu kesatuan sitem. Hardware digunakan sebagai media untuk menjalankan perangkat lunak (software) dan peralatan ini berfungsi untuk menjalankan intruksi-intruksi yang diberikan dan dikeluarkannya dalam bentuk informasi yang digunakan oleh manusia untuk laporan. Spesifikasi perangkat keras yang digunakan untuk menginplementasikan website ini adalah sebagai berikut

1. Leptop Asus X441M

2. Intel Celeron $\mathrm{N} 4000$, up to $2,6 \mathrm{GHz}$

3. Layar 14.0 inci

4. Ram 4GB

\subsubsection{Implementasi Antar Muka}

Impementasi antar muka dilakukan dengan membuat antar muka pada form yang ada pada website ini. Adapun termasuk implementasi antar muka adalah sebagai berikut:

1. Buka Xampp Control Panel

Klik Start MySQL

Klik Start FileZilla

locallhost

2. Buka Notepad ++

Berisi Coding pemrograman yang akan ditampilkan

3. Buka Browser : Mozilla Firefox

Klik localhost//phpmyadmin untuk menuju ke database yang akan dibuat 
"db_tokomartijo".

4. Pengisian database yang akan dibuat

5. Klik localhost pada halaman browser, kemudian akan tampil halaman antar muka yang telah tersimpan di dalam database yang dibuat.

\subsubsection{Implementasi Form Login Admin}

Pada form login menampilkan halaman login yang berisi user id dan password yang berfungsi untuk masuk ke halaman administrator.

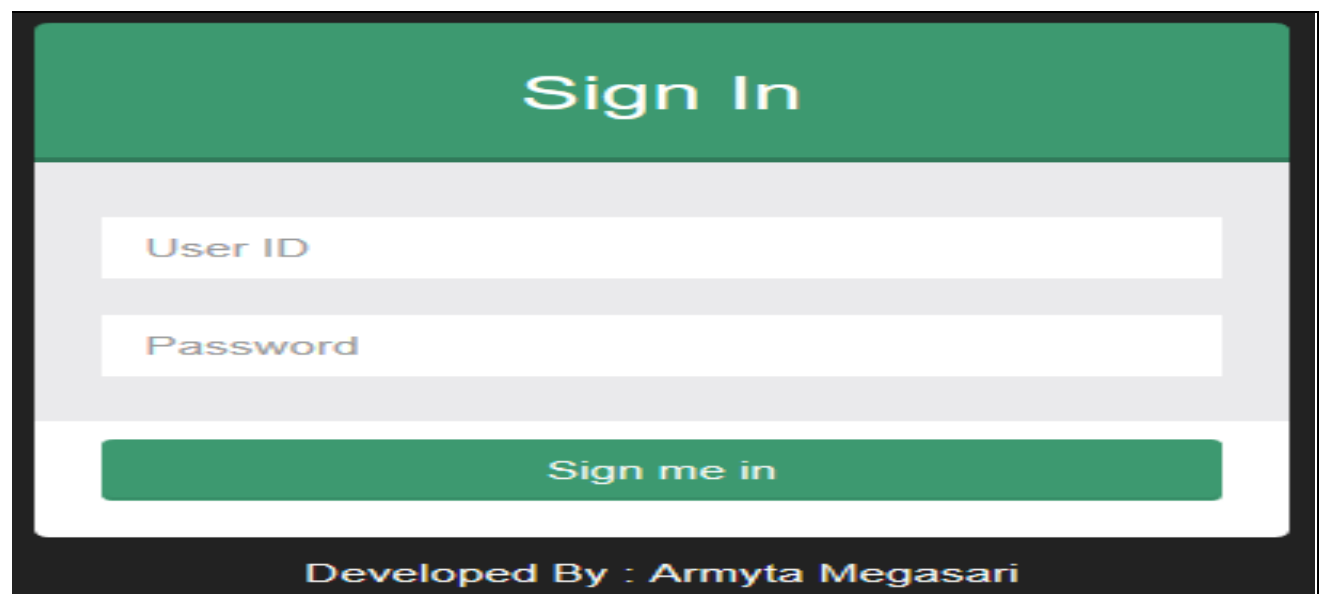

Gambar 4.1 Implementasi Login Admin

\subsubsection{Implementasi Form Login Member}

Pada form login member menampilkan halaman login member yang sudah terdaftar di Toko Martijo 123 jadi konsumen dapat langsung login untuk melakukan transaksi, yang terdiri dari email, password dan id_member yang dapat di isi ketika akan melakukan pemesanan produk pada Toko Martijo.

\section{Account}

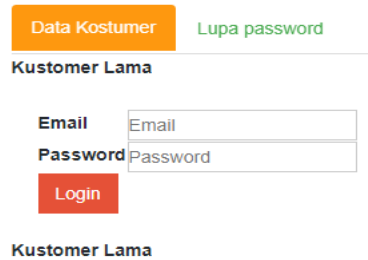

Nomor ID MEMBER Nomor Id Member

Gambar 4.2 Implementasi Login Member

\subsubsection{Implementasi From Login Konsumen}

Pada halaman ini menampilkan halaman login konsumen yang berfungsi untuk melakukan pemesanan produk pada Toko Martijo. Yang terdiri dari fild nama lengkap, email, password, alamat lengkap, no telp, lokasi. 


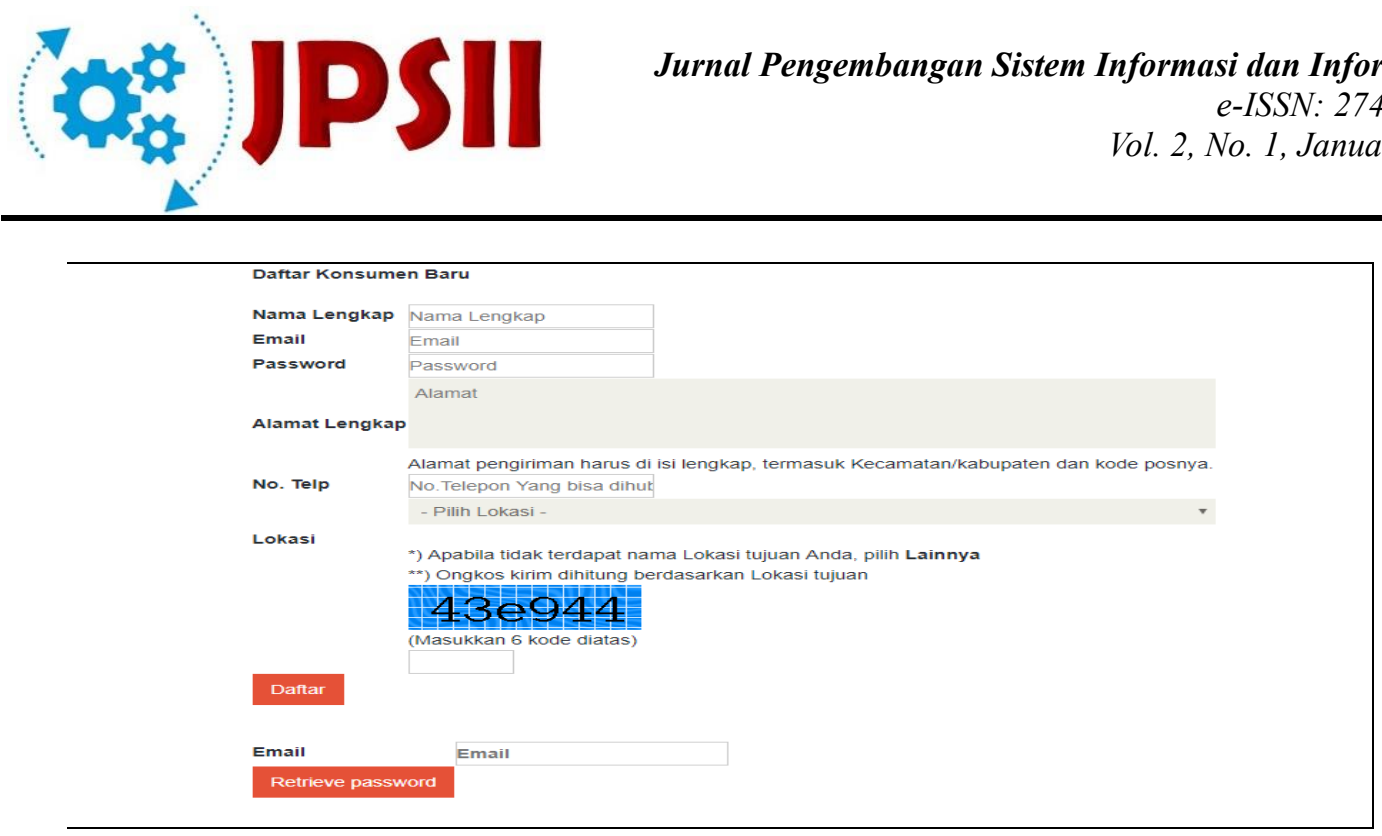

Gambar 4.3 Implementasi Login Konsumen

\subsubsection{Implementasi Halaman Administrator}

Pada halaman ini menampilkan halaman admin yang digunakan untuk mengelolah data yang ada di halaman admin yaitu terdiri dari menu data user, profil konsumen, profil Toko, menu utama, submenu, edit cara beli, data cabang, kategori produk, data produk, ongkos kirim, data kurir, testimonial, promosi, data order, laporan order, lihat bukti pembayaran.

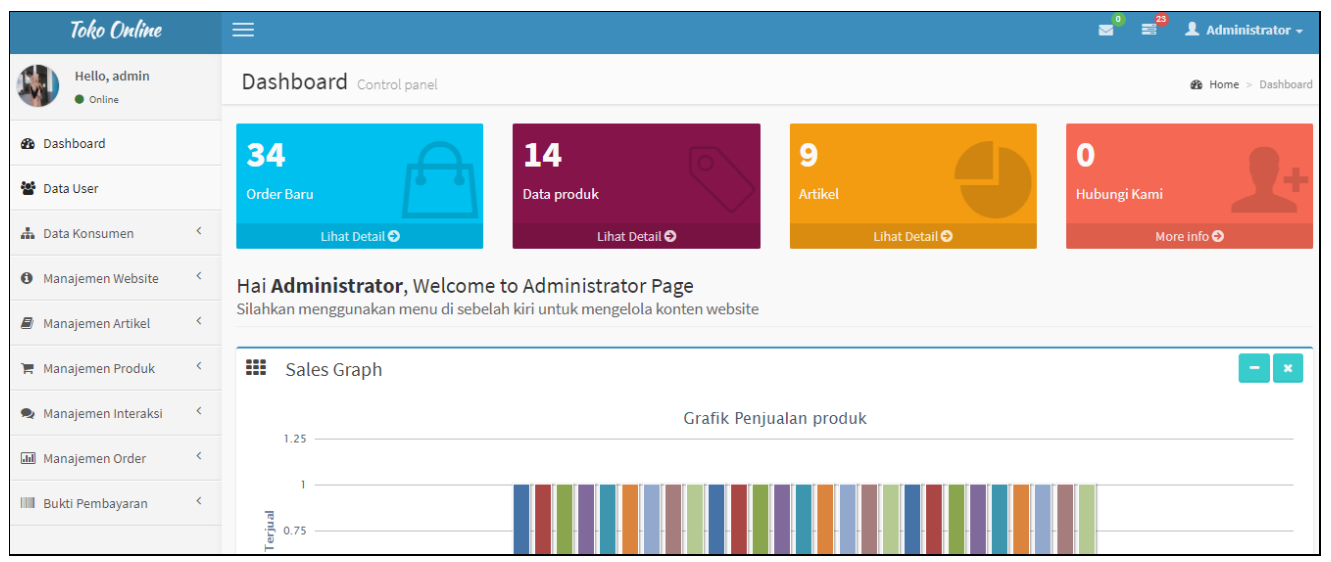

Gambar 4.4 Implementasi Administrator

\subsubsection{Implementasi Data User}

Pada halaman ini menampilkan halaman data user yang berfungsi untuk menampilkan data user, yang terdiri fild user name, nama lengkap, foto user, level, blokir, aksi. 

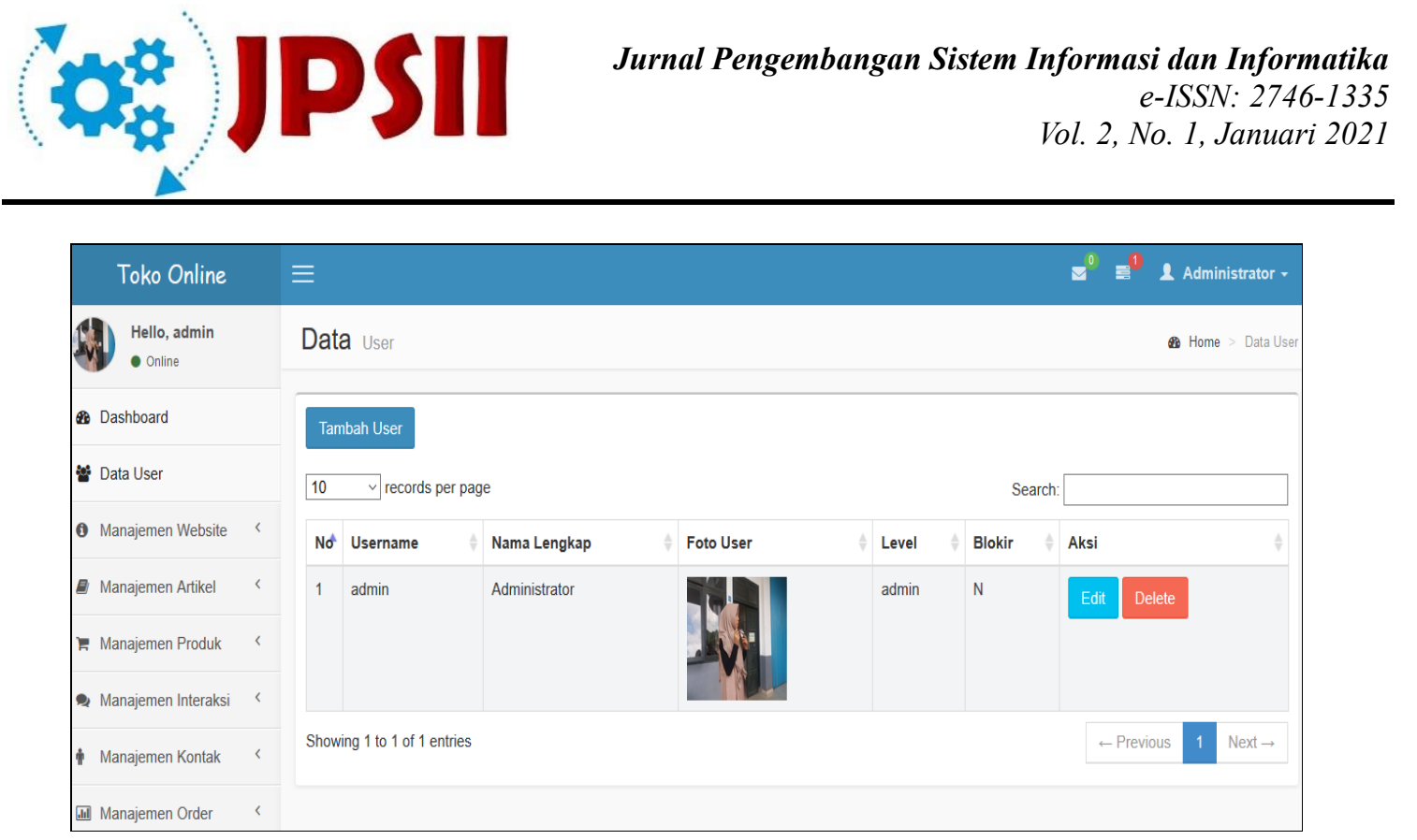

Gambar 4.5 Implementasi Data User

\subsubsection{Implementasi Profil Konsumen}

Pada halaman ini menampilkan halaman profil Konsumen, yang berfungsi untuk menginput data konsumen, yang terdiri dari fild nomor, email, nama lengkap, alamat, telepon, aksi.

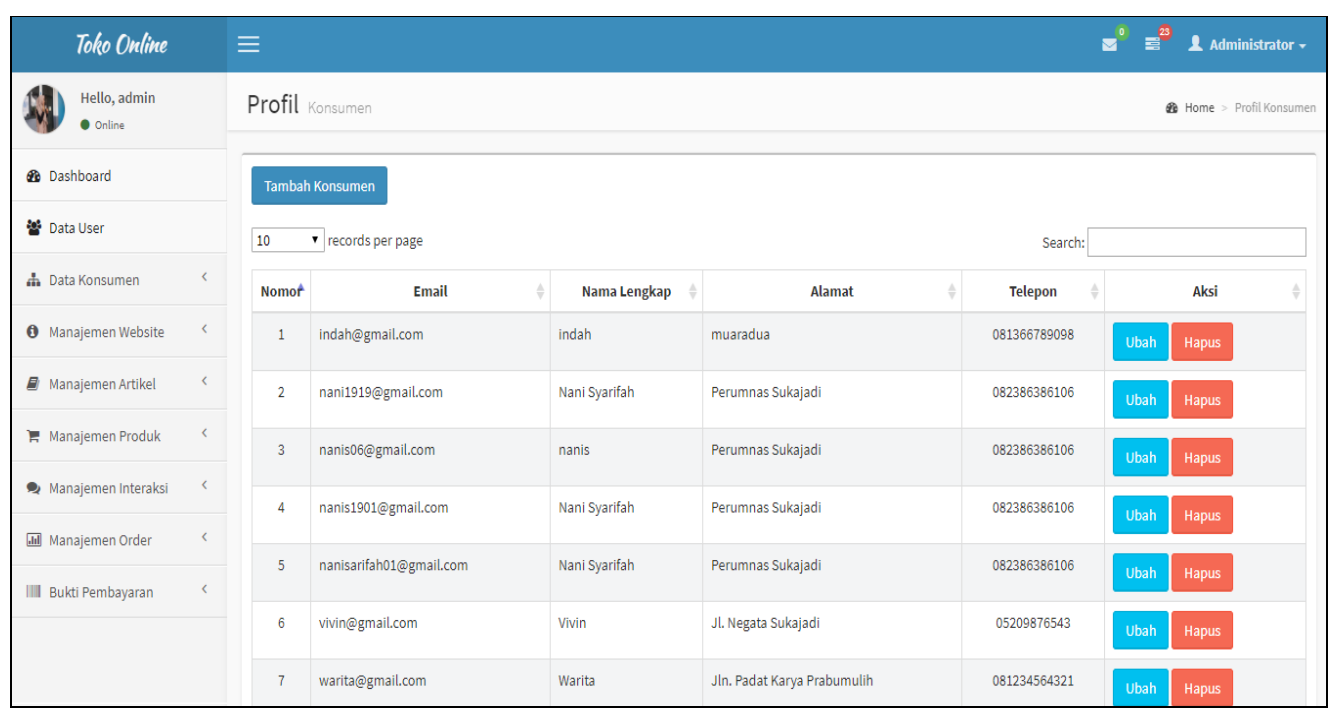

Gambar 4.6 Implementasi Profil Konsumen

\subsubsection{Implementasi Menu Utama}

Pada halaman ini menampilkan halaman menu utama yang berfungsi untuk melakukan peng-inputan dan peng-updatetan data pada submenu di halaman administrator, yang terdiri fild nama menu, link, urutan, status aktif, letak, aksi. 

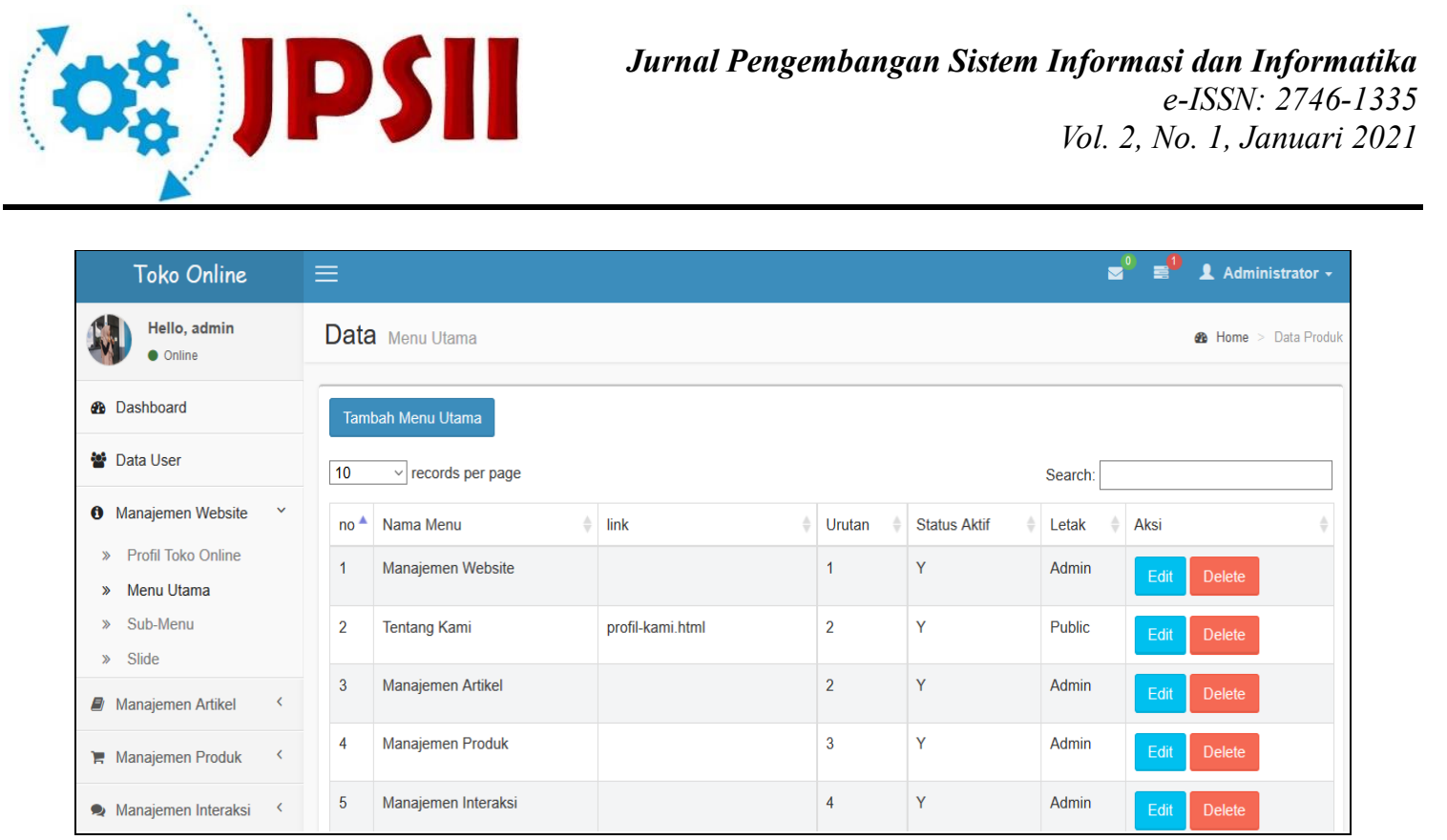

Gambar 4.7 Implementasi Menu Utama

\subsubsection{Implementasi SubMenu}

Pada halaman ini menampilkan halaman submenu yang berfungsi untuk menampilkan submenu yang ada di halaman administrator, yang terdiri dari fild submenu, menu utama, link submenu, aktif, aksi.

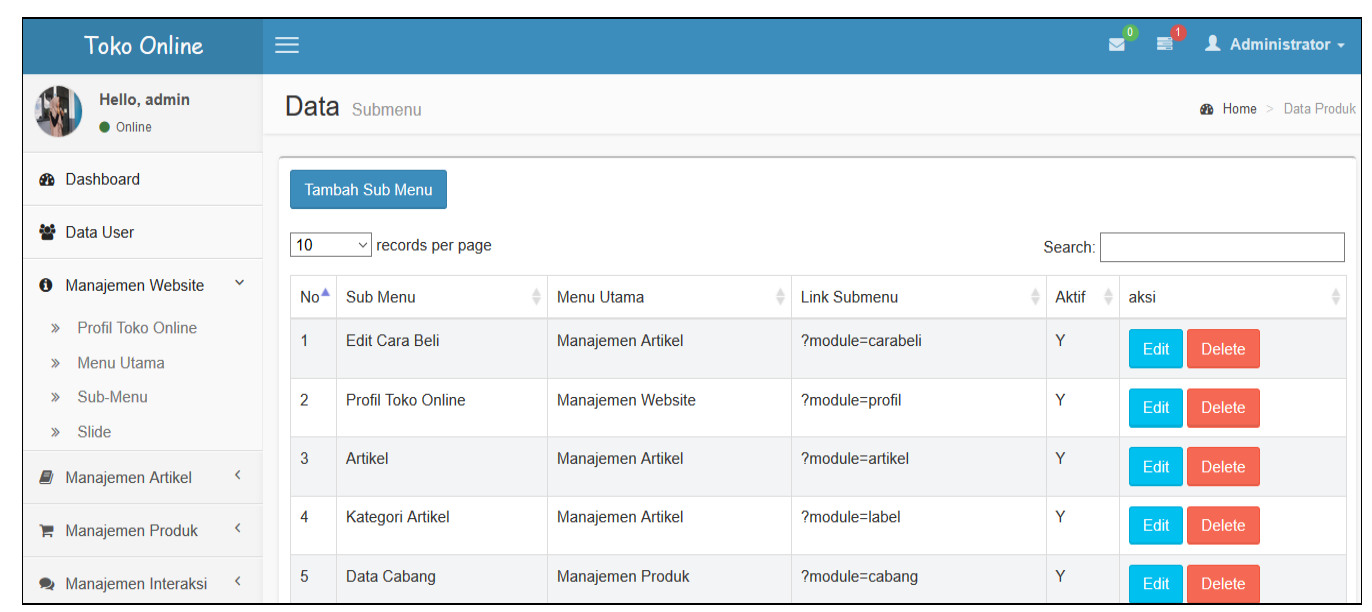

Gambar 4.8 Implementasi SubMenu

\subsection{Pengujian Sistem}

Pengujian sistem merupakan bagian terpenting dalam pembuatan perangkat lunak. Pengujian dilakukan untuk menguji apakah program yang dibuat sudah dapat berjalan sesuai dengan harapan pengguna atau masih ada yang error.

\subsubsection{Rencana Pengujian}

Pengujian sistem dalam penelitian ini dilakukan pengujian Black Box Testing yaitu menguji perangkat lunak dari segi spesifiksi fungsional tanpa menguji desain dan kode program.

Tabel 4.1 Rencana Pengujian

\begin{tabular}{|l|l|l|}
\hline Komponen yang Diuji & Butir yang Diuji & Hasil Pengujian \\
\hline
\end{tabular}




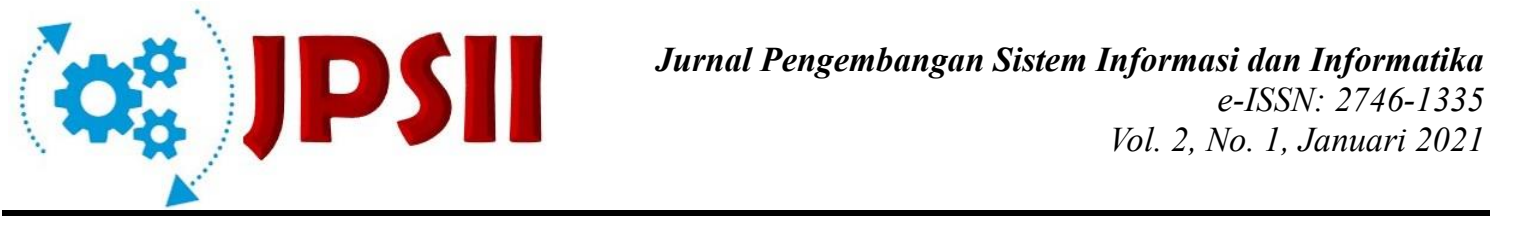

\begin{tabular}{|c|c|c|}
\hline Tampilan Halaman Login admin & Tombol Sign In & Valid \\
\hline Tampilan Halaman Login Member & $\begin{array}{l}\text { Tombol Halaman } \\
\text { Login }\end{array}$ & Valid \\
\hline $\begin{array}{l}\text { Tampilan Halaman } \quad \text { Login } \\
\text { Konsumen }\end{array}$ & $\begin{array}{l}\text { Tombol Halaman } \\
\text { Daftar }\end{array}$ & Valid \\
\hline Tampilan Halaman Input Data User & $\begin{array}{l}\text { Tombol Tambah } \\
\text { User }\end{array}$ & Valid \\
\hline Tampil Halaman Profil Konsumen & $\begin{array}{l}\text { Tombol Tambah } \\
\text { Konsumen }\end{array}$ & Valid \\
\hline Tampilan Halaman Profil Toko & Tombol Simpan & Valid \\
\hline $\begin{array}{l}\text { Tampilan Halaman Input Menu } \\
\text { Utama }\end{array}$ & $\begin{array}{l}\text { Tombol Tambah } \\
\text { Menu Utama }\end{array}$ & Valid \\
\hline Tampilan Halaman Input SubMenu & $\begin{array}{l}\text { Tombol Tambah } \\
\text { SubMenu }\end{array}$ & Valid \\
\hline Tampilan Halaman Cara Beli & Tombol Cara Beli & Valid \\
\hline Tampilan Halaman Data Cabang & $\begin{array}{l}\text { Tombol Tambah } \\
\text { Cabang }\end{array}$ & Valid \\
\hline Tampilan Halaman Kategori Produk & $\begin{array}{l}\text { Tombol Tambah } \\
\text { Kategori Produk }\end{array}$ & Valid \\
\hline Tampilan Halaman Data Produk & $\begin{array}{l}\text { Tombol Tambah } \\
\text { Kategori Produk }\end{array}$ & Valid \\
\hline Tampilan Halaman Ongkos Kirim & $\begin{array}{l}\text { Tombol Tambah } \\
\text { Ongkos Kirim }\end{array}$ & Valid \\
\hline Tampilan Halaman Data Kurir & $\begin{array}{l}\text { Tombol Tambah } \\
\text { Kurir }\end{array}$ & Valid \\
\hline Tampilan Halaman Testimonial & $\begin{array}{l}\text { Tombol Tambah } \\
\text { Testimoni }\end{array}$ & Valid \\
\hline Tampilan Halaman Laporan Order & Tombol Laporan & Valid \\
\hline Tampilan Halaman Home & Tobol Home & Valid \\
\hline Tampilan Halaman Panduan Belanja & Panduan & Valid \\
\hline
\end{tabular}




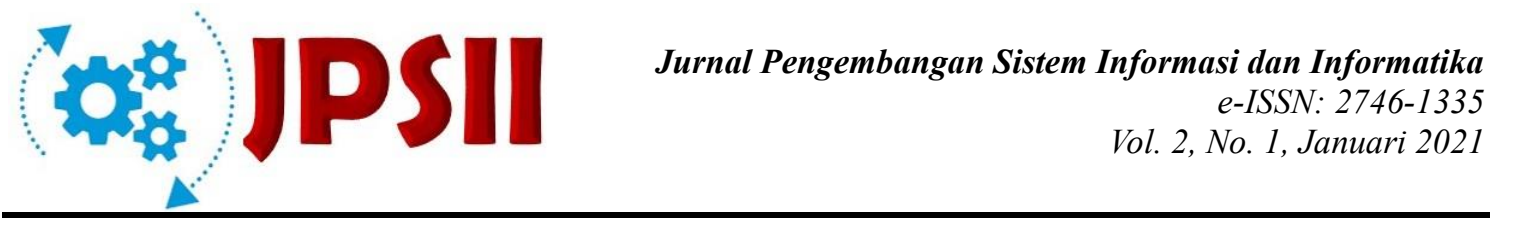

\begin{tabular}{|l|l|c|}
\hline & Belanja & \\
\hline $\begin{array}{l}\text { Tampilan Halaman Bukti } \\
\text { Pembayaran }\end{array}$ & $\begin{array}{l}\text { Tombol Bukti } \\
\text { pembayaran }\end{array}$ & Valid \\
\hline Tampilam Halaman Tentang Kami & $\begin{array}{l}\text { Tombol Tentang } \\
\text { Kami }\end{array}$ & Valid \\
\hline Tampilam Halaman Promosi & $\begin{array}{l}\text { Tombol Tambah } \\
\text { Promosi }\end{array}$ & Valid \\
\hline
\end{tabular}

\subsubsection{Hasil Pengujian}

Pengujian sistem dilakukan untuk memastikan komponen dari sistem ini telah berjalan sesuai dengan yang diaharpkan atau tidak dan mencari kesalahan yang mungkin terjadi. Berikut hasil pengujian sistem :

Tabel 4.2 Hasil Pengujian Halaman Login Admin

\begin{tabular}{|l|l|l|l|c|}
\hline Kasus Uji & \multicolumn{1}{|c|}{ Alur Uji } & Aksi & $\begin{array}{l}\text { Hasil yang } \\
\text { diharapkan }\end{array}$ & Hasil Uji \\
\hline $\begin{array}{l}\text { Halaman } \\
\text { Login admin }\end{array}$ & $\begin{array}{l}\text { Memilih Tombol } \\
\text { Sign In }\end{array}$ & Klik & $\begin{array}{l}\text { Menampilkan } \\
\text { Login admin }\end{array}$ & Valid \\
\hline
\end{tabular}

Tabel 4.3 Hasil Pengujian Login Member

\begin{tabular}{|l|l|c|l|c|}
\hline Kasus Uji & \multicolumn{1}{|c|}{ Alur Uji } & Aksi & \multicolumn{1}{|c|}{$\begin{array}{l}\text { Hasil yang } \\
\text { diharapkan }\end{array}$} & Hasil Uji \\
\hline $\begin{array}{l}\text { Halaman } \\
\begin{array}{l}\text { Login } \\
\text { Member }\end{array}\end{array}$ & $\begin{array}{l}\text { Memilih Tombol } \\
\text { Login }\end{array}$ & Klik & $\begin{array}{l}\text { Menampilkan Login } \\
\text { Member }\end{array}$ & Valid \\
\hline
\end{tabular}

Tabel 4.4 Hasil Pengujian Halaman Login Konsumen

\begin{tabular}{|l|l|c|l|c|}
\hline Kasus Uji & \multicolumn{1}{|c|}{ Alur Uji } & Aksi & \multicolumn{1}{|c|}{$\begin{array}{l}\text { Hasil yang } \\
\text { diharapkan }\end{array}$} & Hasil Uji \\
\hline $\begin{array}{l}\text { Halaman } \\
\text { Login } \\
\text { Konsumen }\end{array}$ & $\begin{array}{l}\text { Memilih Tombol } \\
\text { Login }\end{array}$ & Klik & $\begin{array}{l}\text { Menampilkan Login } \\
\text { Konsumen }\end{array}$ & Valid \\
\hline
\end{tabular}


Tabel 4.5 Hasil Pengujian Halaman Input Data User

\begin{tabular}{|l|l|c|l|c|}
\hline Kasus Uji & \multicolumn{1}{|c|}{ Alur Uji } & Aksi & \multicolumn{1}{|c|}{$\begin{array}{l}\text { Hasil yang } \\
\text { diharapkan }\end{array}$} & Hasil Uji \\
\hline $\begin{array}{l}\text { Halaman } \\
\begin{array}{l}\text { Input Data } \\
\text { User }\end{array}\end{array}$ & $\begin{array}{l}\text { Memilih Tombol } \\
\text { Tambah User }\end{array}$ & Klik & $\begin{array}{l}\text { Menampilkan Input } \\
\text { Data User }\end{array}$ & Valid \\
\hline
\end{tabular}

Tabel 4.6 Hasil Pengujian Halaman Profil Konsumen

\begin{tabular}{|l|l|l|l|c|}
\hline Kasus Uji & \multicolumn{1}{|c|}{ Alur Uji } & Aksi & \multicolumn{1}{|c|}{$\begin{array}{l}\text { Hasil yang } \\
\text { diharapkan }\end{array}$} & Hasil Uji \\
\hline $\begin{array}{l}\text { Halaman } \\
\text { Profil } \\
\text { Konsumen }\end{array}$ & $\begin{array}{l}\text { Memilih Tombol } \\
\text { Tambah Profil } \\
\text { Konsumen }\end{array}$ & Klik & $\begin{array}{l}\text { Menampilkan Profil } \\
\text { Konsumen }\end{array}$ & Valid \\
\hline
\end{tabular}

Tabel 4.7 Hasil Pengujian Halaman Profil Toko

\begin{tabular}{|l|l|c|l|c|}
\hline Kasus Uji & \multicolumn{1}{|c|}{ Alur Uji } & Aksi & \multicolumn{1}{|c|}{$\begin{array}{l}\text { Hasil yang } \\
\text { diharapkan }\end{array}$} & Hasil Uji \\
\hline $\begin{array}{l}\text { Halaman } \\
\text { Profil Toko }\end{array}$ & $\begin{array}{l}\text { Tombol Tambah } \\
\text { Profil Toko }\end{array}$ & Klik & $\begin{array}{l}\text { Menampilkan Profil } \\
\text { Toko }\end{array}$ & Valid \\
\hline
\end{tabular}

Tabel 4.8 Hasil Pengujian Halaman Menu Utama

\begin{tabular}{|l|l|l|l|c|}
\hline Kasus Uji & \multicolumn{1}{|c|}{ Alur Uji } & Aksi & \multicolumn{1}{|l|}{$\begin{array}{l}\text { Hasil yang } \\
\text { diharapkan }\end{array}$} & Hasil Uji \\
\hline $\begin{array}{l}\text { Halaman } \\
\text { Menu } \\
\text { Utama }\end{array}$ & $\begin{array}{l}\text { Memilih Tombol } \\
\text { Tambah Menu } \\
\text { Utama }\end{array}$ & Klik & $\begin{array}{l}\text { Menampilkan Menu } \\
\text { Utama }\end{array}$ & Valid \\
\hline
\end{tabular}

Tabel 4.9 Hasil Pengujian Halaman SubMenu

\begin{tabular}{|l|l|l|l|c|}
\hline Kasus Uji & \multicolumn{1}{|c|}{ Alur Uji } & Aksi & $\begin{array}{l}\text { Hasil yang } \\
\text { diharapkan }\end{array}$ & Hasil Uji \\
\hline $\begin{array}{l}\text { Halaman } \\
\text { SubMenu }\end{array}$ & $\begin{array}{l}\text { Memilih Tombol } \\
\text { Tambah SubMenu }\end{array}$ & Klik & $\begin{array}{l}\text { Menampilkan } \\
\text { SubMenu }\end{array}$ & Valid \\
\hline
\end{tabular}

\section{Kesimpulan}

Berdasarkan perancangan, pembangunan, dan pengujian yang telah dilakukan penulis. telah berhasil membuat website Toko Martijo 123, maka dapat diambil kesimpulan sebagai berikut: 
1. Dengan menerapkan Metode User Centered Design pada website Toko Martijo 123 telah dapat meningkatkan kegunaan website tersebut.

2. Dari hasil analisis kebutuhan perancangan sistem dan pengujian kepada calon pengguna, website Toko Martijo 123 telah berhasil memenuhi kriteria yang sesuai dengan keinginan pengguna dan sesuai dengan prinip User Centered Design.

3. Website Toko Martijo 123 mampu memberikan informasi mengenai produk yang ditawarkan, baik melihat katalog penjualan yang telah diposting secara langsung.

4. Website ini sudah dapat digunakan sebagai sarana penunjang untuk berbagi informasi dan proses jual beli, tentang produk yang ditawarkan oleh Toko Martijo 123.

\section{Referensi}

A.S. Rosa., M. Shalahuddin, Rekaya Perangkat Lunak Terstruktur dan Berorientasi Objek, Bandung: Informatika Bandung, 2011.

A.S. Rosa., M. Shalahuddin, Rekaya Perangkat Lunak Terstruktur dan Berorientasi Objek, Bandung: Informatika Bandung, 2015.

Agus., E-Commerce, E-Business dan Mobile Commerce, Bandung: Informatika Bandung, 2015 .

Antoni, D., \& Akbar, M. (2019). E-supply chain management value concept for the palm oil industry. Jurnal Sistem Informasi, 15(2), 15-29.

Antoni, D., Fikari, D., \& Akbar, M. (2018). The readiness of palm oil industry in enterprise resource planning. Telkomnika, 16(6), 2692-2702.

Antoni, D., Herdiansyah, M. I., Akbar, M., \& Sumitro, A. (2021). Pengembangan Infrastruktur Jaringan Untuk Meningkatkan Pelayanan Publik di Kota Palembang. JURNAL MEDIA INFORMATIKA BUDIDARMA, 5(4), 1652-1659.

Antoni, D., Jie, F., \& Abareshi, A. (2020). Critical factors in information technology capability for enhancing firm's environmental performance: case of Indonesian ICT sector. International Journal of Agile Systems and Management, 13(2), 159-181.

Fauzi, F., Dencik, A. B., \& Asiati, D. I. (2019). Metodologi Penelitian untuk manajemen dan akuntansi. Jakarta: Salemba Empat.

Jelita., Mukharil, "Analisis User Interface Media Pembelajaran Pengenalan Kosakata Untuk Anak Tunarungu," KOMPUTA, pp. 45-54, 2017.

Josi., Fajriyah, "Rancang Bangun Sistem Informasi Tender Karet Desa Jungai Menggunakan Metode Waterfall," SISFOKOM, vol. 6, no 2, pp. 111-115, 2017.

Jubilee., Enterprise, PHP Komplet, Jakarta: Elex Media Komputindo, 2017.

Mikhael., Heri, "Sistem Informasi Penjualan Berbasis Web Pada PT Era Makmur Cahaya Damai Bekasi," Information System for Educators And Professionals, vol. 1, no. 2, pp. 175-188, 2017.

Mulyadi, Sistem Akuntansi, Jakarta: Salemba Empat, 2001. 
Nazir., Moh, Metode Penelitian, Bogor: Ghalia Indonesia, 2011.

Priyo., Eko, Bikin Sendiri Toko Online Dinamis Dengan Bootstrap dan PHP, Yogyakarta:Media Kom, 2016.

Rahman., Su, Rahasia Membuat Website dan SEO Paling Mudah dengan RVSiteBuilder Pro, Jakarta: Elex Media Komputindo, 2014.

Riko., "Penerapan Metode User Centered Design Untuk perancangan Aplikasi Radio Streaming Berbasis Web," INTI, vol. 3, no. 1, pp . 1-5, 2014.

Sugiyono, Metode Penelitian Kuantitatif, Kualitatif dan R\&D, Bandung: Alfabeta, 2015.

Yuntari, "Rancang Bangun Aplikasi penjualan Dan Persediaan Obat Pada Apotek Marben Di Prabumulih,” JSK, vol. 1, no. 1, pp. 81-188, 2017.

\section{Copyrights}

Copyright for this article is retained by the author(s), with first publication rights granted to the journal.

This is an open-access article distributed under the terms and conditions of the Creative Commons Attribution license (http://creativecommons.org/licenses/by/4.0/) 